\title{
Time preferences and lifetime outcomes
}

Citation for published version (APA):

Golsteyn, B. H. H., Grönqvist, H., \& Lindahl, L. (2013). Time preferences and lifetime outcomes.

Maastricht University, Graduate School of Business and Economics. GSBE Research Memoranda No. 065 https://doi.org/10.26481/umagsb.2013065

Document status and date:

Published: 01/01/2013

DOI:

10.26481/umagsb.2013065

Document Version:

Publisher's PDF, also known as Version of record

\section{Please check the document version of this publication:}

- A submitted manuscript is the version of the article upon submission and before peer-review. There can be important differences between the submitted version and the official published version of record.

People interested in the research are advised to contact the author for the final version of the publication, or visit the DOI to the publisher's website.

- The final author version and the galley proof are versions of the publication after peer review.

- The final published version features the final layout of the paper including the volume, issue and page numbers.

Link to publication

\footnotetext{
General rights rights.

- You may freely distribute the URL identifying the publication in the public portal. please follow below link for the End User Agreement:

www.umlib.nl/taverne-license

Take down policy

If you believe that this document breaches copyright please contact us at:

repository@maastrichtuniversity.nl

providing details and we will investigate your claim.
}

Copyright and moral rights for the publications made accessible in the public portal are retained by the authors and/or other copyright owners and it is a condition of accessing publications that users recognise and abide by the legal requirements associated with these

- Users may download and print one copy of any publication from the public portal for the purpose of private study or research.

- You may not further distribute the material or use it for any profit-making activity or commercial gain

If the publication is distributed under the terms of Article $25 \mathrm{fa}$ of the Dutch Copyright Act, indicated by the "Taverne" license above, 


\section{Maastricht University}

Bart H.H. Golsteyn,

Hans Grönqvist, Lena Lindahl

Time preferences and lifetime outcomes

RM/13/065

\section{GSBE}

Maastricht University School of Business and Economics

Graduate School of Business and Economics

P.O Box 616

NL-6200 MD Maastricht

The Netherlands 


\title{
Time preferences and lifetime outcomes ${ }^{1}$
}

\author{
by \\ Bart H.H. Golsteyn ${ }^{2}$, Hans Grönqvist ${ }^{3}$ and Lena Lindahl ${ }^{4}$
}

October 14, 2013

\begin{abstract}
This paper investigates the relationship between time preferences and lifetime social and economic behavior. We use a Swedish longitudinal dataset that links information from a large survey on children's time preferences at age 13 to administrative registers spanning over four decades. Our results indicate a substantial adverse relationship between high discount rates and school performance, health, labor supply, and lifetime income. Males and high ability children gain significantly more from being future-oriented. These discrepancies are largest regarding outcomes later in life. We also show that the relationship between time preferences and long-run outcomes operates through early human capital investments.
\end{abstract}

Keywords: Intertemporal choice; personality, preference parameter, human capital; income; health.

JEL-codes: D03, D91, J01

\footnotetext{
${ }^{1}$ We received valuable comments from Anders Björklund, Thomas Dohmen, Markus Jäntti, Matthew Lindquist, Anna Sjögren, Bas ter Weel, conference participants of the 2011 ESPE and the 2012 ESSLE meetings and seminar participants at the Institute for Evaluation of Labour Market and Education Policy (IFAU). Golsteyn thanks the Volkswagen Stiftung and Handelsbanken's forskningsstiftelser for financial support; Grönqvist acknowledges funding from FAS and Handelsbanken's forskningsstiftelser; Lindahl thanks FAS and IFAU for financing part of this research.

${ }^{2}$ Department of Economics and Research Centre for Education and the Labour Market (ROA),Maastricht University, P.O. Box 616, 6200 MD, Maastricht, the Netherlands, and Swedish Institute for Social Research (SOFI), Stockholm University, SE-106 91 Stockholm, Sweden, b.golsteyn@maastrichtuniversity.nl.

${ }^{3}$ Swedish Institute for Social Research (SOFI), Stockholm University, SE-106 91 Stockholm, Sweden, hans.gronqvist@sofi.su.se.

${ }^{4}$ Swedish Institute for Social Research (SOFI), Stockholm University, SE-106 91 Stockholm, Sweden, lena.lindahl@sofi.su.se.
} 
Every day people make decisions that involve balancing costs and benefits occurring at different points in time.Such choices include whether or not to drop out of school, search for a new job, or start saving. Intertemporal decision making has been a cornerstone in many economic models since Samuelson (1937), and a salient feature in human capital theory, where the notion is that people with high discount rates invest less in their future than people who are more futureoriented (e.g. Mincer 1958; Becker 1964). As the full returns to many human capital investments are not revealed until after some time, it is remarkable that there are only few empirical studies which link time preferences to long-term outcomes. ${ }^{5}$ This lacuna is especially evident regarding investments made early in life. Needless to say, childhood represents a critical period when many important investments are made with potentially life-lasting consequences. With a small number of exceptions (e.g. Mischel, Shoda and Rodriguez 1989; Cadena and Keys 2011), the existing evidence on the connection between time preferences and real world outcomes is cross-sectional in nature and focuses on the adult population.

This paper investigates the relationship between time preferences during childhood and longrun social and economic outcomes. We use a Swedish longitudinal dataset that links surveybased information on 11,907 children's time preferences at age 13 to administrative registers spanning over four decades. Time preferences are measured through a questionnaire in which children are asked to rate the extent to which they prefer SEK 900 (USD 130) today over SEK 9,000(USD 1,300) in five years. ${ }^{6}$ We document how time preferences are related to human capital investments in terms of educational choices and school performance as early as in compulsory school. We then follow the children throughout life, observing their completed education, results on military enlistment tests, fertility decisions, indicators of health, labor market success, and lifetime income. ${ }^{7}$

Our results indicate that time preferences are strongly associated with lifetime outcomes. ${ }^{8} \mathrm{~A}$ higher discount rate is linked to weaker performance in both compulsory and secondary school, lower educational attainment, and lower scores on military achievement tests at age 19. The

\footnotetext{
${ }^{5}$ We use the terms impatience, high discount rate and high rate of time preference as synonyms.

${ }^{6}$ In 2012 year's price level.

7 The literature on economic preference parameters typically focuses on the predictive value of preferences. Causal effects are not possible to elicit since - even in the setting of a laboratory where the researcher can control many aspects - it would not be possible to design an experiment which influences time preferences only. One cannot exclude the possibility that other preferences are influenced as well by the experiment. Our paper highlights the importance of the predictive value of high time preferences at a young age. We make a step in the direction of analyzing the robustness of our findings to important potential confounders by controlling for individual and parental characteristics and by analyzing withintwin differences.

${ }^{8}$ This result is related to the work by Heckman, Stixrud and Urzua (2006) and Heineck and Anger (2010), who find evidence that personality traits predict later in life outcomes.
} 
magnitude of the discrepancy in compulsory school performance between more and less futureoriented children is substantial and similar to the gender gap in performance between boys and girls. We also document an adverse relation with lifetime income, unemployment, welfare takeup, early death, obesity and teenage childbearing. Our results hold even after controlling for potentially important confounding factors such as parental socioeconomic status and cognitive ability. ${ }^{9}$ In an attempt to also partly control for the influence of genes and unobserved family influences, we compare outcomes within twin-pairs included in our sample. We also use an alternative measure of time discounting obtained from a factor analysis of other questions included in the survey. The results from both these exercises corroborate our main findings.

We continue by studying the association between time preferences and lifetime outcomes in different segments of the population. Our results show that being future-oriented is a more important trait for men when predicting long-run outcomes than for women. The same holds for individuals who scored above average on a spatial ability test included in the survey. Interestingly, while correlations between time preferences and earnings and disposable income are larger for females and low ability individuals at age 27, the correlations become larger for males and high ability individuals later in life.

A key result in our paper is that the relationship between time preferences and lifetime outcomes is mediated by early human capital investments. There is some evidence that time preferences are malleable and that interventions in childhood environment may contribute in shaping time preferences. ${ }^{10}$ The results in our paper would in this case imply that early interventions that make individuals more future-oriented potentially bring lifelong benefits.

The strength and novelty of our study lie in the use of a very rich data source. The data enable us to link time preferences during childhood to social and economic outcomes observed for a very long portion of the respondents' lives. We measure time preferences at age 13 and are able to follow individuals for more than four decades. No other data have enabled researchers to analyze the importance of time preferences for such an extended period. An additional substantial benefit is that our data is taken from a large sample of Swedish citizens with little scope for selection into or out of the sample. The survey at age 13 had a mandatory character since it was conducted in schools and all pupils present at school during that particular day took part in the survey. The outcomes later in life are taken from administrative registers so there is hardly any attrition in the data. A third benefit of our data is that it allows us to control for results on cognitive ability tests that were part of the survey. We believe that this is important,

\footnotetext{
${ }^{9}$ E.g. Dohmen et al. (2010) and Burks et al. (2009) report that time preferences and cognitive ability are related.

${ }^{10}$ We discuss evidence on the malleability of time preferences in the results section.
} 
given the results in recent research that time preferences and ability interact in the adult population (Dohmen et al 2010; Shamosh and Gray, 2007).

Most earlier studies on the relationship between time preferences and outcomes are crosssectional in nature or follow individuals over a short period of time. For instance, some studies have documented that time preferences in the adult population are significantly correlated with field outcomes such as occupational choice (Burks et al. 2009), credit card borrowing (Meier and Sprenger 2010b), and substance use and nutrition (Chabris et al. 2008). Recent articles by Sutter et al. (2011), Bettinger and Slonim (2007) and Castillo et al. (2011) focus on time preferences among children. Sutter et al. (2011) relate risk attitudes and time preferences to health-related field behavior and savings decisions in an experimental setting. They find crosssectional evidence that discount rates among 661 children aged 10 to 18 correlate with their Body Mass Index (BMI) and savings as well as spending on alcohol and tobacco. Bettinger and Slonim (2007) measure time preferences among approximately 200 5-16 year old children and find hyperbolic preferences, differences between boys and girls, and racial differences. Their cross-sectional evidence does not reveal a correlation with school achievement. Castillo et al. (2011) show that one standard deviation increase in the elicited discount rate among 880 children aged 13 to 15 is associated with an increase in the number of disciplinary referrals in the following school year of 14 percent.

Only few previous studies have been able to follow their subjects over a longer period of time and the focus of these investigations is on the concept of self-control. The seminal work by Walter Mischel and co-authors analyze the relationship between self-control and children's subsequent behavior (see Mischel, Shoda and Peake, 1988, Mischel, Shoda and Rodriguez, 1989, and Shoda, Mischel and Peake, 1990). Their experiment measured delay of gratification by the time children aged four could wait for a larger treat relative to a smaller immediate treat. Around one decade later, the children who were able to delay their gratification for the longest period also scored highest on achievement tests. The sample used was very small (95 children). Another psychological study in the same spirit but with a somewhat larger sample size is performed by Moffitt et al. (2011), who at various ages attempt to measure self-control by a composite that among other things incorporates parental-teacher ratings of children's aggression, hyperactivity, and impulsivity, with self reports of attention problems and observational ratings of restlessness and stamina, for a cohort of around 1,000 New-Zealand children. They follow the children from age 3 to 32 and find substantial positive effects of the composite on health, wealth and crime. Related to this, in Economics, a recent study by Cadena and Keys (2011) focuses on outcomes related to education and earnings using data from the National Longitudinal Survey of Youth (NLSY). Since the NLSY does not contain a direct 
measure of time preferences, the authors use as a proxy for time preference: the assessment of the interviewer whether (s)he perceived the respondent as restless. The results suggest that restless individuals did worse in terms of educational attainment and labor supply in young adulthood. ${ }^{11}$

Besides the difference in the magnitude of the samples, the length of the period in which the children were followed, and the relevance and range of outcomes observed, one important difference between our paper and this research lies in the measurement of the trade-off between the present and the future. The children in the work by Mischeland co-authors attempt to control their current appetite while they make the trade-off between the present and the future. The measure therefore in essence conflates self-control and standard exponential discounting. ${ }^{12,} 13$ The authors acknowledge this by referring to this measure as "future-oriented self-control" (Mischel, Shoda and Rodriguez, 1989, p. 281).Since our measure entails a hypothetical monetary trade-off between the present and the future, there is no reason to believe that this measure of time preferences is related to self-control problems. It is further unclear to what extent factors like aggression and inattention provide an accurate representation of time preferences.

The set-up of the paper is as follows. Section 2 describes the data, section 3 shows the results and section 4 concludes.

\section{Data}

We use data from the Stockholm Birth Cohort Study (SBC), created in 2004/2005 by means of a probability matching of two previously existing longitudinal data sets. ${ }^{14}$ The first is the Stockholm Metropolitan Study 1953-1985, which consists of all children born in 1953 who were living in the Stockholm metropolitan area on November 1, 1963. This data source contains a rich set of variables concerning individual, family, social and neighborhood characteristics. The second is The Swedish Work and Mortality Database, an administrative data set which includes

\footnotetext{
${ }^{11}$ Restlessness was measured rather late in the respondents' lives: at age 15-27. By that age, most individuals already have undertaken important human capital investments, making the analysis to some extent susceptible to reverse causality.

${ }^{12}$ Restlessness may also indicate self-control problems.

${ }^{13}$ Self-control problems may for instance arise due to visceral influences (e.g. hunger). They generate inconsistencies in intertemporal preferences. A model in which future utility is discounted quasihyperbolically can illustrate the conceptual difference between exponential discounting and self-control problems (e.g. Laibson 1994, 1997). In this model, utility falls very rapidly for small delay periods (due to self-control problems), while it falls more slowly and regularly for longer delay periods. Both the extent to which people consistently prefer the present relative to the future (delta) and the extent to which they face self-control problems (beta) may be of importance for future outcomes.

${ }^{14}$ See Stenberg and Vågerö (2006) for a full description of the dataset and the matching procedure. Codebooks are available online: http://www.stockholmbirthcohort.su.se/about-the-project/original-data1953-1983.
} 
information on education, income, work, unemployment and mortality for all individuals living in Sweden in 1980 or 1990 who were born before 1985. The database contains information on the individuals up to 2001.

The SBC study includes survey data from a school study that was conducted in 1966 when the cohort members were 13 years old. During one school day, pupils at practically all schools in the county filled out two questionnaires, including the question which we use to elicit time preferences, and took a spatial cognitive ability test which we use to measure cognitive ability. An important aspect of the survey is that it took place at school which gave it a mandatory character. As a result, the non-response rate is only 9 percent (the percentage of pupils absent on that particular school day). The low non-response rate in combination with the fact that the survey was given to all students in the county is likely to increase the external validity of our study. ${ }^{15}$ A concern with laboratory based studies is that the participants may be self-selected on the basis of their discount rate. Impatient individuals could for example be less likely to sign up for participation in a laboratory experiment. ${ }^{16}$ On the other hand, as in many other studies we rely on a hypothetical question about individual time preferences and it is not obvious that stated choices perfectly correspond to actual ones.

We measure time preferences using the following question: "If you had to choose between SEK 900 [USD 130] now versus SEK 9,000 [USD 1,300] in five years, which would you choose?”17 The set of possible answers was: "Certainly SEK 900 now” (1), "Probably SEK 900 now” (2), “Cannot choose” (3), "Probably SEK 9000 in five years” (4), “Certainly SEK 9000 in five years" (5). In our regressions we treat the answers as flexible as possible and include dummies for the different categories. To simplify the presentation of the results, we also use a single dummy set to unity if the answer belonged to categories 4 or 5 and zero otherwise.

Figure 1 shows the distribution of the answers. In spite of the very high implied annual discount rate of 58\%, 13\% of the children state that they prefer SEK 900 (USD 130) today over SEK 9,000 (USD 130) in five years. The discount rate is well in line with discount rates used in

\footnotetext{
${ }^{15}$ Given the nature of our data it is relevant to ask whether our results can be generalized to other contexts. First, we can note that at the time when the data were collected, the Stockholm metropolitan area covered about one fourth of the Swedish population, so quite a large part of the population is covered. Secondly, Lindahl (2011) compares summary statistics for both the SBC data and a nationally representative sample also born in 1953 and finds, as expected, similar income averages and variances in the SBC data. Her estimates are also very similar to those found in Norwegian studies based on nationally representative samples. This suggest that our sample should at the very least be representative for the Swedish population.

${ }^{16}$ Related to this, von Gaudecker, van Soest and Wengström (2011) find that people in a laboratory have substantially lower risk preferences than subjects drawn from the (Dutch) population and that the heterogeneity among subjects in the laboratory is much lower than that in the population wide sample. However they also show that self-selection into the experiments did much less harm than sampling from a narrowly defined distribution, such as a student population.

${ }^{17}$ Note that these amounts are presented in current prices.
} 
other experimental and field studies (see e.g. Frederick et al. 2002). Bettinger and Slonim (2007) report that one third of their sample of children turned down a 150 percent return in two months in favor of immediately receiving compensation.

Our data contain many outcomes that are expected to be related to human capital investments. Human capital theory posits that people with high discount rates invest less in education than people who prefer to delay their rewards (e.g. Mincer 1958, Becker, 1964). We observe grades in compulsory school and high school and the highest level completed with a diploma (e.g. high school, college). The grade point averages are taken from local school registers in grade nine in compulsory school and in the last year of upper secondary school. ${ }^{18}$

We also observe achievement test scores at military enlistment (at age 19), calculated as an average of four sub-tests including rapid comprehension, inductive ability, verbal comprehension and spatial ability. Such enlistment test scores are often interpreted as measures of cognitive ability but may also be described as achievement test scores: a reflection of acquired knowledge (Borghans et al., 2012). Scores on achievement tests are related to cognitive ability but also associated with personality traits (Borghans et al., 2012; Segal, 2012). Next to this, we analyze the link between discounting and educational attainment as well as the choice of whether or not to enroll in science track in high school.

Our next set of outcomes relates to long-run labor market performance. Time preferences may not only be related to human capital investments but could also predict labor supply decisions. DellaVigna and Paserman (2005) show that impatient individuals accept a lower reservation wage, but stay unemployed longer than patient individuals. Data on long-run labor market outcomes are collected from several sources. We use the 1980 Census to collect information on earnings and disposable income at age 27. Administrative registers available between the years 1990 to 2001 are used to examine earnings and disposable income at age 37 and 47 respectively. We also proxy long-run income by averaging incomes between ages 37 and 48 years (see e.g. Haider and Solon; Böhlmark and Lindquist 2006).For the same period we calculate the average annual number of unemployment days per year and the share of years receiving welfare.

We also study the relationship between time preferences and health. Grossman (1972) posits that an individual's discount rate is adversely related to health investments so that individuals who are less future-oriented invest less in their health. There is cross-sectional evidence on this relationship but no longitudinal evidence. Fuchs (1982) found weak relationships between time preferences and smoking. Bickel, Odum and Madden (1999) find that people with high time

\footnotetext{
${ }^{18}$ In the 1960 s, grades were on a scale of $1-5$ and relative to the performance of other students. The population grade distribution was assumed to be normal, which generates a national average for each cohort of 3.0.
} 
preferences are more likely to be smoking. Borghans and Golsteyn (2006) show that high time discounters have a higher BMI. We analyze whether time preferences are related to obesity (BMI>30) at military enlistment and early death (by age 50).

The original SBC data set matched with administrative registers consists of 13,606 observations. After selecting out observations with missing values on the time preferences variable, our data contains 11,907 observations. Table A 1 gives the descriptive statistics of the variables included in our analysis.

Before proceeding to our results it is useful to illustrate the correlation between time preferences and various individual characteristics. Table A 2 provides least squares estimates where the dependent variable is a dummy set to unity if the child with certainty or almost certainty prefers to delay his/her rewards and zero otherwise. We can see that ability and gender are strongly correlated with time preferences. A one standard deviation higher ability at age 13 is related with 2.3 percentage points (or approximately 5\%) higher likelihood of being patient. Women are 2.4 percentage points less likely to have preferences for delaying the timing of their rewards. Considering the particular age at which time preferences are measured, (age 13), it could be the case that this difference has some connection to puberty. Girls of this age have, on average, gone longer in the process of puberty than boys. The finding of more impatient girls is in line with the findings in Dohmen et al. (2010). ${ }^{19}$ Due to the young age and potential variation in maturity among the children in the sample, it might be important to examine the correlation between time preferences and the age of the child. If time preferences are affected by a child's maturity, it could be the case that December-born children are more impatient than children born in January. This is potentially important also since it is well known that children who are born earlier during the year tend to outperform those born later (see e.g. Bound et al. 1995). As shown in Table A 2, this is not supported by our data.

Additionally, we investigate the role of parental socio-economic status for their children's time preferences. Parental income was taken from the official tax register in 1963, i.e. prior to the survey. We find a significant association between parental socioeconomic status and time preferences. Children to parents with higher education tend to be more future-oriented. The relationship between parental income and time preferences is ambiguous: a positive association for fathers' income and a negative one for mothers' income. Not only does this finding stress the need to control for parental socioeconomic status in the regressions but it is also suggestive evidence that time preferences may be malleable.

\footnotetext{
${ }^{19}$ Jamison, Karland and Zinman (2012) report that there is no clear consensus on whether time preferences differ between men and women but the preponderance of evidence suggests that women have lower discount rates than men (see e.g. Castillio et al., 2011 and Bettinger and Slonim, 2007).
} 


\section{$3 \quad$ Results}

This section presents the results of our analysis of the link between time preferences and lifetime outcomes. We start by examining early measures of human capital. Then we proceed to investigating the relationship between time preferences and long-run labor market outcomes and health.

Our main analysis includes two sets of estimates. The first uses dummies for all categories of the question on time preferences. The reference group here is individuals who with certainty prefer the immediate reward, i.e. impatient persons. The second specification pools different categories of the time preferences variable into a dummy that equals one if the individual with certainty or almost certainty prefers to delay the timing of reward and zero otherwise. In order to conserve space we use this single dummy variable when performing robustness checks and subgroup analyses. All regressions control for month of birth, gender, the educational level of the parent with the highest education (three levels), each parent's income (linearly) and each parent's year of birth (linearly). We only present estimates for our main variable of interest. The estimates of the control variables can be found in the appendix.

Table 1 reveals that a low discount rate is an important trait for a successful school career. People who were more patient at age 13 achieved higher grades in compulsory school and in upper secondary school. Next to this, they more often enrolled in the science track in upper secondary school. Patience also correlates positively with the likelihood of attaining an upper secondary school or university diploma.

The magnitude of the estimated coefficients is sizable. We find that individuals who prefer to delay their reward have 0.21 standard deviations higher GPA in compulsory school and 0.20 standard deviations higher GPA in upper secondary school. There are also indications of a "dose-response" relationship between the outcomes and the different answer categories. Individuals who are completely certain that they want to delay the timing of reward tend to have better outcomes than those who probably want to delay the reward. We can also see that individuals who delay their reward are 5.9 percentage points (or about 30 percent) more likely to attend the science track in upper secondary school. ${ }^{20}$ Patience also increases the probability to attain an upper secondary school diploma with approximately 8.5 percentage points and the likelihood to complete college with 5.3 percentage points. Table 1 additionally shows that patient boys achieve 0.21 standard deviation higher scores on the military enlistment achievement test.

\footnotetext{
${ }^{20}$ Note that since impatience is related to attaining a high school diploma, the relationship between impatience and high school GPA is likely to be underestimated.
} 
The relationship between time preferences and human capital appears to be strongest among individuals who were absolutely certain that they would choose the immediate reward. This can be seen by examining the individual coefficients on the multiple dummies. From these it is clear that there is a large difference in the outcomes between the reference group and children who responded that they probably would choose the immediate reward. Even though the magnitude of the coefficient increases in the degree of certainty in which an individual would choose the delayed reward over the immediate reward, the jump is largest between children that would certainly compared to probably prefer the immediate reward.

After having documented a link between time preferences and early measures of human capital we proceed to looking at long-run income in Table 2. In this analysis we focus on earnings and disposable income. We observe these outcomes at three points during the life span: at the ages of 27, 37 and 47 . We also use average annual income between the age of 37 and 48 . Time preferences are strongly associated with earnings and income at all periods in life. Again we find that the coefficients are sizable and almost always statistically significant. Being more patient is related to substantially higher earnings and disposable income. For example, at the age of 27, individuals who answered that they certainly preferred to delay the timing of reward have about 6.4 percent higher income than those who were certain that they wanted the immediate reward. Interestingly, the connection between patience and earnings seem to grow stronger later in life. At age 37, the corresponding figure is 7.4 percent and at age 47 it is 11.0 percent. The same pattern also holds for disposable income. One explanation of this result is that income at younger ages is a more noisy measure of lifetime income. If so, our results show that it is crucial to have information on income over an extended period in order to correctly assess the relationship between time preferences and an individual's true earnings capacity. Note that the size of the estimates for disposable income is slightly lower than for earnings. One reason for this result may be that disposable income includes government transfers which are likely to be less strongly correlated with an individual's time preferences. 
Table 1. Time preferences and educational achievement

\begin{tabular}{|c|c|c|c|c|c|c|}
\hline & $\begin{array}{l}\text { Compulsory } \\
\text { school GPA } \\
\text { (standardized) }\end{array}$ & $\begin{array}{l}\text { Upp. sec. school } \\
\text { GPA } \\
\text { (standardized) }\end{array}$ & $\begin{array}{l}\text { Completed upp. } \\
\text { sec. school }\end{array}$ & $\begin{array}{l}\text { Completed } \\
\text { college }\end{array}$ & $\begin{array}{l}\text { Enrolled in } \\
\text { science track in } \\
\text { upp. sec. school }\end{array}$ & $\begin{array}{l}\text { Enlistment test } \\
\text { scores } \\
\text { (standardized) }\end{array}$ \\
\hline \multicolumn{7}{|l|}{ A. } \\
\hline $\begin{array}{l}\text { Timing of reward: } \\
\text { Certainly immediate }\end{array}$ & Ref. & Ref. & Ref. & Ref. & Ref. & Ref. \\
\hline Probably immediate & $\begin{array}{l}0.281^{* * *} \\
(0.049)\end{array}$ & $\begin{array}{l}0.141^{*} \\
(0.082)\end{array}$ & $\begin{array}{l}0.107 * * * \\
(0.024)\end{array}$ & $\begin{array}{l}0.040 * * \\
(0.016)\end{array}$ & $\begin{array}{l}-0.025 \\
(0.030)\end{array}$ & $\begin{array}{l}0.227 * * * \\
(0.076)\end{array}$ \\
\hline Indifferent & $\begin{array}{l}0.194 * * * \\
(0.046)\end{array}$ & $\begin{array}{l}0.115 \\
(0.080)\end{array}$ & $\begin{array}{l}0.072 * * * \\
(0.022)\end{array}$ & $\begin{array}{l}0.025^{*} \\
(0.014)\end{array}$ & $\begin{array}{l}0.022 \\
(0.031)\end{array}$ & $\begin{array}{l}0.084 \\
(0.071)\end{array}$ \\
\hline Probably delay & $\begin{array}{l}0.372^{* * *} \\
(0.039)\end{array}$ & $\begin{array}{l}0.276^{* * *} \\
(0.069)\end{array}$ & $\begin{array}{l}0.144 * * * \\
(0.018)\end{array}$ & $\begin{array}{l}0.072^{* * *} \\
(0.012)\end{array}$ & $\begin{array}{l}0.039 \\
(0.026)\end{array}$ & $\begin{array}{l}0.338 * * * \\
(0.057)\end{array}$ \\
\hline Certainly delay & $\begin{array}{l}0.383^{* * * *} \\
(0.038)\end{array}$ & $\begin{array}{l}0.316 * * * \\
(0.069)\end{array}$ & $\begin{array}{l}0.154^{* * *} \\
(0.018)\end{array}$ & $\begin{array}{l}0.086^{* * *} \\
(0.012)\end{array}$ & $\begin{array}{l}0.051 * * \\
(0.026)\end{array}$ & $\begin{array}{l}0.337 * * * \\
(0.055)\end{array}$ \\
\hline $\begin{array}{l}\text { Full set of controls } \\
\text { R-squared }\end{array}$ & $\begin{array}{l}\text { Incl. } \\
0.113\end{array}$ & $\begin{array}{l}\text { Incl. } \\
0.085\end{array}$ & $\begin{array}{l}\text { Incl. } \\
0.120\end{array}$ & $\begin{array}{l}\text { Incl. } \\
0.119\end{array}$ & $\begin{array}{l}\text { Incl. } \\
0.068\end{array}$ & $\begin{array}{l}\text { Incl. } \\
0.055\end{array}$ \\
\hline $\begin{array}{l}\text { Timing of reward: } \\
\text { Immediate or indifferent }\end{array}$ & Ref. & Ref. & Ref. & Ref. & Ref. & Ref. \\
\hline Delay & $\begin{array}{l}0.210 * * * \\
(0.027)\end{array}$ & $\begin{array}{l}0.196 * * * \\
(0.042)\end{array}$ & $\begin{array}{l}0.085^{* * *} \\
(0.013)\end{array}$ & $\begin{array}{l}0.053 * * * \\
(0.009)\end{array}$ & $\begin{array}{l}0.059 * * * \\
(0.016)\end{array}$ & $\begin{array}{l}0.214^{* * * *} \\
(0.041)\end{array}$ \\
\hline $\begin{array}{l}\text { Full set of controls } \\
\text { R-squared }\end{array}$ & $\begin{array}{l}\text { Incl. } \\
0.108\end{array}$ & $\begin{array}{l}\text { Incl. } \\
0.082\end{array}$ & $\begin{array}{l}\text { Incl. } \\
0.117\end{array}$ & $\begin{array}{l}\text { Incl. } \\
0.117\end{array}$ & $\begin{array}{l}\text { Incl. } \\
0.067\end{array}$ & $\begin{array}{l}\text { Incl. } \\
0.049\end{array}$ \\
\hline Observations & 11,120 & 5,649 & 11,907 & 11,907 & 5,649 & 6,047 \\
\hline
\end{tabular}

Notes: The table shows the coefficients on dummies set to unity if the child at age 13 probably prefers SEK 900 (USD 130) today versus SEK 9,000 (USD 130) in five years, is indifferent, or either probably or certainly prefers SEK 9,000 in five years. All regressions are estimated by OLS. Each column represents a separate regression. The sample consists of children born in Stockholm county in 1953. All regressions control for dummies for month of birth, gender, educational level (3 levels) of the parent with the highest education, each parent's income (linearly) and each parent's year of birth (linearly). $* * *=$ significant at the $1 \%$ level $* *=$ significant at the $5 \%$ level* = significant at the $10 \%$ level. 
Table 2. Time preferences and income over life

\begin{tabular}{|c|c|c|c|c|c|c|c|c|}
\hline & \multicolumn{4}{|c|}{ log(Earnings) } & \multicolumn{4}{|c|}{$\log$ (Disposable income) } \\
\hline & Age 27 & Age 37 & Age 47 & $\begin{array}{l}\text { Long-term } \\
\text { income }\end{array}$ & Age 27 & Age 37 & Age 47 & $\begin{array}{l}\text { Long-term } \\
\text { income }\end{array}$ \\
\hline \multicolumn{9}{|l|}{ A. } \\
\hline $\begin{array}{l}\text { Timing of reward: } \\
\text { Certainly immediate }\end{array}$ & Ref. & Ref. & Ref. & Ref. & Ref. & Ref. & Ref. & Ref. \\
\hline Probably immediate & $\begin{array}{l}0.042 \\
(0.044)\end{array}$ & $\begin{array}{l}0.047 \\
(0.037)\end{array}$ & $\begin{array}{l}0.097 * * \\
(0.043)\end{array}$ & $\begin{array}{l}0.074 \\
(0.045)\end{array}$ & $\begin{array}{l}0.024 \\
(0.040)\end{array}$ & $\begin{array}{l}0.065^{* *} \\
(0.027)\end{array}$ & $\begin{array}{l}0.091 * * * \\
(0.032)\end{array}$ & $\begin{array}{l}0.054^{* *} \\
(0.023)\end{array}$ \\
\hline Indifferent & $\begin{array}{l}0.078 * * \\
(0.039)\end{array}$ & $\begin{array}{l}0.073^{* *} \\
(0.032)\end{array}$ & $\begin{array}{l}0.097 * * \\
(0.040)\end{array}$ & $\begin{array}{l}0.054 \\
(0.043)\end{array}$ & $\begin{array}{l}0.056 \\
(0.036)\end{array}$ & $\begin{array}{l}0.049^{*} \\
(0.025)\end{array}$ & $\begin{array}{l}0.074 * * \\
(0.029)\end{array}$ & $\begin{array}{l}0.033 \\
(0.022)\end{array}$ \\
\hline Probably delay & $\begin{array}{l}0.076^{* *} \\
(0.033)\end{array}$ & $\begin{array}{l}0.061^{* *} \\
(0.029)\end{array}$ & $\begin{array}{l}0.114^{* * *} \\
(0.034)\end{array}$ & $\begin{array}{l}0.124 * * * \\
(0.036)\end{array}$ & $\begin{array}{l}0.064 * * \\
(0.030)\end{array}$ & $\begin{array}{l}0.075^{* * *} \\
(0.022)\end{array}$ & $\begin{array}{l}0.099 * * * \\
(0.025)\end{array}$ & $\begin{array}{l}0.078 * * * \\
(0.018)\end{array}$ \\
\hline Certainly delay & $\begin{array}{l}0.064 * \\
(0.033)\end{array}$ & $\begin{array}{l}0.074 * * * \\
(0.028)\end{array}$ & $\begin{array}{l}0.110 * * * \\
(0.034)\end{array}$ & $\begin{array}{l}0.111^{* * *} \\
(0.036)\end{array}$ & $\begin{array}{l}0.054 * \\
(0.030)\end{array}$ & $\begin{array}{l}0.082 * * * \\
(0.021)\end{array}$ & $\begin{array}{l}0.112 * * * \\
(0.025)\end{array}$ & $\begin{array}{l}0.078 * * * \\
(0.018)\end{array}$ \\
\hline $\begin{array}{l}\text { Full set of controls } \\
\text { R-squared }\end{array}$ & $\begin{array}{l}\text { Incl. } \\
0.056 \\
\end{array}$ & $\begin{array}{l}\text { Incl. } \\
0.093 \\
\end{array}$ & $\begin{array}{l}\text { Incl. } \\
0.053 \\
\end{array}$ & $\begin{array}{l}\text { Incl. } \\
0.052 \\
\end{array}$ & $\begin{array}{l}\text { Incl. } \\
0.054 \\
\end{array}$ & $\begin{array}{l}\text { Incl. } \\
0.046 \\
\end{array}$ & $\begin{array}{l}\text { Incl. } \\
0.049 \\
\end{array}$ & $\begin{array}{l}\text { Incl. } \\
0.063 \\
\end{array}$ \\
\hline Immediate or indifferent & Ref. & Ref. & Ref. & Ref. & Ref. & Ref. & Ref. & Ref. \\
\hline Delay & $0.049 * *$ & $0.044 * *$ & $0.060 * * *$ & $0.071^{* * *}$ & $0.046 * *$ & $0.042^{* * *}$ & $0.056^{* * *}$ & $0.045 * * *$ \\
\hline & $(0.023)$ & $(0.020)$ & $(0.023)$ & $(0.024)$ & $(0.021)$ & $(0.015)$ & $(0.017)$ & $(0.013)$ \\
\hline Full set of controls & Incl. & Incl. & Incl. & Incl. & Incl. & Incl. & Incl. & Incl. \\
\hline R-squared & 0.055 & 0.093 & 0.053 & 0.052 & 0.054 & 0.045 & 0.048 & 0.062 \\
\hline Observations & 11,537 & 11,032 & 10,392 & 11,456 & 11,648 & 11,556 & 11,252 & 11,193 \\
\hline
\end{tabular}

Notes: The table shows the coefficients on dummies set to unity if the child at age 13 probably prefers SEK 900 (USD 130) today versus SEK 9,000 (USD 130) in five years, is indifferent, or either probably or certainly prefers SEK 9,000 in five years. All regressions are estimated by OLS. Each column represents a separate regression. The sample consists of children born in Stockholm county in 1953. All regressions control for dummies for month of birth, gender, educational level (3 levels) of the parent with the highest education, each parent's income (linearly) and each parent's year of birth (linearly). Long-term income is calculated as average over age $37-48 . * * *=$ significant at the $1 \%$ level $* *=$ significant at the $5 \%$ level $*=$ significant at the $10 \%$ level. 
Table 3 displays results for other dependent variables related to labor supply, health and fertility. We can see that patience significantly predicts less use of welfare and fewer days on unemployment between the ages of 37 and 48 . Children who at age 13 preferred to delay the timing of reward had for instance 1.6 fewer unemployment days per year at middle age. In relation to the mean of the dependent variable this translates into a reduction of about 15 percent.

Time preferences are also significantly related to health outcomes. In Table 3 we see that patient men are 1.5 percentage points less likely to be classified as obese at military enlistment. Patient respondents are also 0.9 percentage points less likely to die before age 50 . Our findings for obesity are in line with the results in Borghans and Golsteyn (2006) who study the relationship between time preferences and the BMI among adults. As discussed by Borghans and Golsteyn, one reason may be that impatient people may value candy, fast food and other instant satisfiers more than patient people.

Table 3. The link between time preferences and welfare, unemployment, obesity, death and teenage pregnancy

\begin{tabular}{lccccc}
\hline & $\begin{array}{c}\text { Share of } \\
\text { years on } \\
\text { welfare }\end{array}$ & $\begin{array}{c}\text { Annual } \\
\text { unemploy- } \\
\text { ment days }\end{array}$ & $\begin{array}{c}\text { Obese at } \\
\text { enlistment }\end{array}$ & Early death & Teenage mother \\
\hline A. Timing of reward: & & & & & \\
& & & & & \\
Certainly immediate & Ref. & Ref. & Ref. & Ref. & Ref. \\
Probably immediate & $-0.016^{*}$ & -0.123 & $-0.030^{* *}$ & -0.012 & $-0.033^{* *}$ \\
& $(0.009)$ & $(1.772)$ & $(0.012)$ & $(0.010)$ & $(0.015)$ \\
Indifferent & -0.007 & -1.119 & $-0.023^{*}$ & -0.013 & $-0.026^{*}$ \\
& $(0.009)$ & $(1.598)$ & $(0.012)$ & $(0.009)$ & $(0.015)$ \\
Probably delay & $-0.026^{* * *}$ & $-2.418^{*}$ & $-0.030^{* * *}$ & $-0.019^{* *}$ & $-0.033^{* *}$ \\
& $(0.007)$ & $(1.383)$ & $(0.011)$ & $(0.008)$ & $(0.013)$ \\
Certainly delay & $-0.020^{* * *}$ & -1.256 & $-0.034^{* * *}$ & $-0.013^{*}$ & $-0.027^{* *}$ \\
& $(0.007)$ & $(1.384)$ & $(0.011)$ & $(0.008)$ & $(0.013)$ \\
Full set of controls & Incl. & Incl. & Incl. & Incl. & Incl. \\
R-squared & 0.023 & 0.006 & 0.796 & 0.006 & 0.014 \\
\hline B. Timing of reward: & & & & & \\
Immediate or indifferent & Ref. & Ref. & Ref. & Ref. & Ref. \\
Delay & $-0.013^{* * *}$ & $-1.654^{*}$ & $-0.015^{* *}$ & $-0.009^{*}$ & -0.011 \\
& $(0.005)$ & $(0.944)$ & $(0.006)$ & $(0.005)$ & $(0.008)$ \\
Full set of controls & Incl. & Incl. & Incl. & Incl. & Incl. \\
R-squared & 0.021 & 0.006 & 0.796 & 0.005 & 0.012 \\
\hline Observations & 11,696 & 11,657 & 11,907 & 11,907 & 5,860 \\
\hline
\end{tabular}

Notes: The table shows the coefficients on dummies set to unity if the child at age 13 probably prefers SEK 900 (USD 130) today versus SEK 9,000 (USD 130) in five years, is indifferent, or either probably or certainly prefers SEK 9,000 in five years. All regressions control for dummies for month of birth, gender, educational level (3 levels) of the parent with the highest education, each parent's income (linearly) and each parent's year of birth (linearly). The dependent variables Share of years on welfare and Annual unemployment days are calculated as the average over age 37-48. $* * *=$ significant at the $1 \%$ level $* *=$ significant at the $5 \%$ level* = significant at the $10 \%$ level. 


\subsection{Sensitivity analyses}

We next set out to examine the robustness of our results to changes in the specification of the regressions or the way we measure time preferences. The results are shown in Table 4 . We first investigate how sensitive our results are to dropping controls for parental background. As already mentioned, children's answers to the survey could reflect parental socioeconomic status. If this is the case we would expect our estimates to change when not controlling for parental education and income. As can be seen in Table 4, the coefficients indeed become larger (in absolute terms) when excluding these controls. However, the change is small, which suggests that failure to control for parental socioeconomic status does not bias the estimates in a meaningful way.

In an attempt to further control for potential confounders we take advantage of the fact that our data contain information on twins who we can identify and link to their parents. We estimate within-twin fixed effect models that control for all factors shared by the twins (regardless whether these are environmental of genetic). Since there are only 117 pairs of twins in the data our estimates naturally become imprecise and almost none of the coefficients are statistically significant. The point estimates however reveal that in many cases both the sign and the magnitude of the coefficients are similar to those in our full sample.

As a final robustness check we use the principal component of answers on a battery of other questions included in the survey which are plausibly linked to time preferences. The questions can be found in the appendix. To facilitate interpretation of the results we choose to standardize the factor variable to have mean zero and unit standard deviation. Looking at Table 4 we see that using this alternative measure of time preferences does not change our conclusions: increased patience still predicts more favorable outcomes throughout life. 
Table 4. Robustness checks

\begin{tabular}{|c|c|c|c|c|}
\hline & Baseline & $\begin{array}{l}\text { No control } \\
\text { for parental } \\
\text { background }\end{array}$ & $\begin{array}{l}\text { Within- } \\
\text { twin } \\
\text { analysis }\end{array}$ & $\begin{array}{l}\text { Measuring time } \\
\text { preferences } \\
\text { using } \\
\text { standardized } \\
\text { factor variable }\end{array}$ \\
\hline \multicolumn{5}{|l|}{ Dependent variable: } \\
\hline Compulsory school GPA (Std.) & $\begin{array}{l}0.210 * * * \\
(0.027)\end{array}$ & $\begin{array}{l}0.250 * * * \\
(0.028)\end{array}$ & $\begin{array}{l}-0.072 \\
(0.180)\end{array}$ & $\begin{array}{l}0.042 * * * \\
(0.009)\end{array}$ \\
\hline Upper sec. school GPA (Std.) & $\begin{array}{l}0.196^{* * * *} \\
(0.042)\end{array}$ & $\begin{array}{l}0.209 * * * \\
(0.042)\end{array}$ & $\begin{array}{l}0.254 \\
(0.332)\end{array}$ & $\begin{array}{l}0.027^{* *} \\
(0.014)\end{array}$ \\
\hline Completed upper sec. school & $\begin{array}{l}0.085 * * * \\
(0.013)\end{array}$ & $\begin{array}{l}0.105^{* * *} \\
(0.014)\end{array}$ & $\begin{array}{l}0.086 \\
(0.095)\end{array}$ & $\begin{array}{l}0.021^{* * *} \\
(0.004)\end{array}$ \\
\hline Completed college & $\begin{array}{l}0.053 * * * \\
(0.009)\end{array}$ & $\begin{array}{l}0.068 * * * \\
(0.009)\end{array}$ & $\begin{array}{l}0.073 \\
(0.077)\end{array}$ & $\begin{array}{l}0.015 * * * \\
(0.003)\end{array}$ \\
\hline Science track in upper sec. school & $\begin{array}{l}0.059 * * * \\
(0.016)\end{array}$ & $\begin{array}{l}0.066^{* * *} \\
(0.016)\end{array}$ & N/A & $\begin{array}{l}-0.005 \\
(0.006)\end{array}$ \\
\hline Enlistment test (Std.) & $\begin{array}{l}0.214 * * * \\
(0.041)\end{array}$ & $\begin{array}{l}0.242 * * * \\
(0.041)\end{array}$ & N/A & $\begin{array}{l}-0.004 \\
(0.013)\end{array}$ \\
\hline Log(earnings) age 27 & $\begin{array}{l}0.049 * * \\
(0.023)\end{array}$ & $\begin{array}{l}0.048 * * * \\
(0.023)\end{array}$ & $\begin{array}{l}0.284 \\
(0.167)\end{array}$ & $\begin{array}{l}-0.009 \\
(0.008)\end{array}$ \\
\hline Log(earnings) age 37 & $\begin{array}{l}0.044 * * \\
(0.020)\end{array}$ & $\begin{array}{l}0.051 * * * \\
(0.020)\end{array}$ & $\begin{array}{l}-0.096 \\
(0.145)\end{array}$ & $\begin{array}{l}0.016 * * * \\
(0.007)\end{array}$ \\
\hline Log(earnings) age 47 & $\begin{array}{l}0.060 * * * \\
(0.023)\end{array}$ & $\begin{array}{l}0.071^{* * *} \\
(0.023)\end{array}$ & $\begin{array}{l}0.085 \\
(0.214)\end{array}$ & $\begin{array}{l}0.022 * * * \\
(0.008)\end{array}$ \\
\hline Log(long-run earnings) & $\begin{array}{l}0.071 * * * \\
(0.024)\end{array}$ & $\begin{array}{l}0.083 * * * \\
(0.024)\end{array}$ & $\begin{array}{l}0.266 \\
(0.253)\end{array}$ & $\begin{array}{l}0.022 * * * \\
(0.009)\end{array}$ \\
\hline Log(disp. income) age 27 & $\begin{array}{l}0.046 * * * \\
(0.021)\end{array}$ & $\begin{array}{l}0.047 * * * \\
(0.021)\end{array}$ & $\begin{array}{l}0.271 \\
(0.203)\end{array}$ & $\begin{array}{l}-0.011 \\
(0.007)\end{array}$ \\
\hline Log(disp. income) age 37 & $\begin{array}{l}0.042 * * * \\
(0.015)\end{array}$ & $\begin{array}{l}0.048 * * * \\
(0.015)\end{array}$ & $\begin{array}{l}0.064 \\
(0.137)\end{array}$ & $\begin{array}{l}0.014 * * * \\
(0.005)\end{array}$ \\
\hline Log(disp. income) age 47 & $\begin{array}{l}0.056^{* * *} \\
(0.017)\end{array}$ & $\begin{array}{l}0.068 * * * \\
(0.017)\end{array}$ & $\begin{array}{l}-0.046 \\
(0.112)\end{array}$ & $\begin{array}{l}0.010 \\
(0.007)\end{array}$ \\
\hline Log(long-run disp. income) & $\begin{array}{l}0.045^{* * *} \\
(0.013)\end{array}$ & $\begin{array}{l}0.055 * * * \\
(0.013)\end{array}$ & $\begin{array}{l}0.111 \\
(0.088)\end{array}$ & $\begin{array}{l}0.015^{* * *} \\
(0.005)\end{array}$ \\
\hline Annual days unemployed & $\begin{array}{l}-1.654^{*} \\
(0.944)\end{array}$ & $\begin{array}{l}-1.873^{* *} \\
(0.942)\end{array}$ & $\begin{array}{l}-8.719 \\
(11.96)\end{array}$ & $\begin{array}{l}-0.232 \\
(0.009)\end{array}$ \\
\hline Share of years on welfare & $\begin{array}{l}-0.013^{* * *} \\
(0.005)\end{array}$ & $\begin{array}{l}-0.015^{* * *} \\
(0.005)\end{array}$ & $\begin{array}{l}-0.068 * \\
(0.041)\end{array}$ & $\begin{array}{l}-0.002 \\
(0.002)\end{array}$ \\
\hline Obese at enlistment (males only) & $\begin{array}{l}-0.015^{* *} \\
(0.006)\end{array}$ & $\begin{array}{l}-0.015^{* * *} \\
(0.006)\end{array}$ & N/A & $\begin{array}{l}0.002 \\
(0.002)\end{array}$ \\
\hline Early death & $\begin{array}{l}-0.009 * \\
(0.005)\end{array}$ & $\begin{array}{l}0.015 * * * \\
(0.016)\end{array}$ & N/A & $\begin{array}{l}-0.001 \\
(0.002)\end{array}$ \\
\hline Teenage mother & $\begin{array}{l}-0.011 \\
(0.008) \\
\end{array}$ & $\begin{array}{l}-0.012 * \\
(0.008) \\
\end{array}$ & N/A & $\begin{array}{l}-0.003 \\
(0.002)\end{array}$ \\
\hline \multicolumn{5}{|c|}{$\begin{array}{l}\text { Notes: Each cell presents the coefficient of the time preference dummy variable (0 if the child at age } 13 \\
\text { probably or certainly prefers SEK } 900 \text { (USD 130) today versus SEK 9,000 (USD 130) in five years, or is } \\
\text { indifferent, and } 1 \text { if it either probably or certainly prefers SEK 9,000 in five years) from a separate } \\
\text { regression where the dependent variable is given in the left column. The sample consists of children born } \\
\text { in Stockholm county in 1953. Regressions in column } 1,2 \text { and } 4 \text { are estimated by OLS, while column } 3 \\
\text { presents fixed effect estimates. All regressions except those in column } 2 \text { control for dummies for month } \\
\text { of birth, gender, educational level ( } 3 \text { levels) of the parent with the highest education, each parent's } \\
\text { income (linearly) and each parent's year of birth (linearly). Long-term income is calculated as average } \\
\text { over age } 37-48 . * * *=\text { significant at the } 1 \% \text { level } * *=\text { significant at the } 5 \% \text { level* = significant at the } 10 \\
\% \text { level. }\end{array}$} \\
\hline
\end{tabular}




\subsection{Extensions of the analysis}

Having established that our results are robust to changes in the empirical specification and how we measure time preferences, we continue by analyzing whether the link between time preferences and lifetime outcomes differs for various segments of the population. An interesting question is whether the relationships differ between men and women or between people with high and low cognitive ability. An important stream of literature indicates large gaps between women and men with respect to education and later in life outcomes, such as wages. Likewise, scores on IQ tests have often been shown to be highly predictive of such future outcomes. The question we can analyze with our data is how patience affects such outcomes for men, women, high and low ability children. Information about the elasticities of patience and the outcomes for these subgroups can give a first indication of the potential effectiveness of investments in patience to alleviate the gaps. We analyze this by running separate regressions for these groups. Our results are presented in Table 5.

Men appear to benefit more from being patient than women. Both when it comes to early human capital investments and long-run income, being future-oriented is a more important trait for men than for women. For long-run earnings the difference is substantial: while patient males have 12.1 percent higher long-run earnings, the corresponding estimate for women is only 2.8 percent (and not statistically significant). We also find that children who scored above average on the spatial ability test taken at age 13 benefit more from being patient than children with below average ability.

Although the gap is present already in school it is strongest for long-run income and health. 
Table 5. Subgroup analysis

\begin{tabular}{|c|c|c|c|c|c|}
\hline & Baseline & Men & Women & Low ability & High ability \\
\hline $\begin{array}{l}\text { Compulsory school GPA } \\
\text { (Std.) }\end{array}$ & $\begin{array}{l}0.210 * * * \\
(0.027)\end{array}$ & $\begin{array}{l}0.264 * * * \\
(0.041)\end{array}$ & $\begin{array}{l}0.167 * * * \\
(0.035)\end{array}$ & $\begin{array}{l}0.157 * * * \\
(0.036)\end{array}$ & $\begin{array}{l}0.201 * * * \\
(0.036)\end{array}$ \\
\hline $\begin{array}{l}\text { Upper sec. school GPA } \\
\text { (Std.) }\end{array}$ & $\begin{array}{c}0.196 * * * \\
(0.042)\end{array}$ & $\begin{array}{c}0.197 * * * \\
(0.065)\end{array}$ & $\begin{array}{c}0.187 * * * \\
(0.054)\end{array}$ & $\begin{array}{c}0.168 * * * \\
(0.065)\end{array}$ & $\begin{array}{c}0.199 * * * \\
(0.054)\end{array}$ \\
\hline $\begin{array}{l}\text { Completed upper sec. } \\
\text { school }\end{array}$ & $\begin{array}{c}0.085^{* * *} \\
(0.013)\end{array}$ & $\begin{array}{c}0.084^{* * *} \\
(0.019)\end{array}$ & $\begin{array}{c}0.087 * * * \\
(0.018)\end{array}$ & $\begin{array}{c}0.075^{* * *} \\
(0.017)\end{array}$ & $\begin{array}{l}0.07 * * * \\
(0.019)\end{array}$ \\
\hline Completed college & $\begin{array}{c}0.053 * * * \\
(0.009)\end{array}$ & $\begin{array}{c}0.068 * * * \\
(0.013)\end{array}$ & $\begin{array}{c}0.041^{* * *} \\
(0.012)\end{array}$ & $\begin{array}{c}0.036 * * * \\
(0.011)\end{array}$ & $\begin{array}{l}0.06^{* * *} \\
(0.015)\end{array}$ \\
\hline $\begin{array}{l}\text { Science track in upper } \\
\text { sec. school }\end{array}$ & $\begin{array}{c}0.059 * * * \\
(0.016)\end{array}$ & $\begin{array}{c}0.112 * * * \\
(0.025)\end{array}$ & $\begin{array}{l}0.017 \\
(0.02)\end{array}$ & $\begin{array}{c}0.023 * * * \\
(0.02)\end{array}$ & $\begin{array}{c}0.071^{* * *} \\
(0.022)\end{array}$ \\
\hline Enlistment test (Std.) & $\begin{array}{c}0.214^{* * * *} \\
(0.041)\end{array}$ & N/A & N/A & $\begin{array}{c}0.151^{* * *} \\
(0.05)\end{array}$ & $\begin{array}{c}0.177 * * * \\
(0.058)\end{array}$ \\
\hline Log(earnings) age 27 & $\begin{array}{l}0.049 * * \\
(0.023)\end{array}$ & $\begin{array}{c}0.001 \\
(0.026)\end{array}$ & $\begin{array}{c}0.086 * * * \\
(0.037)\end{array}$ & $\begin{array}{l}0.052^{*} \\
(0.031)\end{array}$ & $\begin{array}{c}0.042 \\
(0.035)\end{array}$ \\
\hline Log(earnings) age 37 & $\begin{array}{l}0.044 * * \\
(0.020)\end{array}$ & $\begin{array}{c}0.063 * * * \\
(0.03)\end{array}$ & $\begin{array}{c}0.027 \\
(0.027)\end{array}$ & $\begin{array}{c}0.025 \\
(0.028)\end{array}$ & $\begin{array}{l}0.056 * * \\
(0.029)\end{array}$ \\
\hline Log(earnings) age 47 & $\begin{array}{c}0.060 * * * \\
(0.023)\end{array}$ & $\begin{array}{c}0.076 * * * \\
(0.033)\end{array}$ & $\begin{array}{c}0.046 \\
(0.032)\end{array}$ & $\begin{array}{c}0.029 \\
(0.034)\end{array}$ & $\begin{array}{c}0.076 * * * \\
(0.031)\end{array}$ \\
\hline Log(long-run earnings) & $\begin{array}{c}0.071^{* * *} \\
(0.024)\end{array}$ & $\begin{array}{c}0.121 * * * \\
(0.041)\end{array}$ & $\begin{array}{c}0.028 \\
(0.029)\end{array}$ & $\begin{array}{l}0.006^{*} \\
(0.034)\end{array}$ & $\begin{array}{c}0.116^{* * *} \\
(0.035)\end{array}$ \\
\hline $\begin{array}{l}\text { Log(disp. income) age } \\
27\end{array}$ & $\begin{array}{c}0.046 * * * \\
(0.021)\end{array}$ & $\begin{array}{c}0.002 \\
(0.024)\end{array}$ & $\begin{array}{l}0.08 * * * \\
(0.034)\end{array}$ & $\begin{array}{l}0.064^{*} \\
(0.03)\end{array}$ & $\begin{array}{c}0.024 \\
(0.031)\end{array}$ \\
\hline $\begin{array}{l}\text { Log(disp. income) age } \\
37\end{array}$ & $\begin{array}{l}0.042 * * * \\
(0.015)\end{array}$ & $\begin{array}{l}0.047 * * \\
(0.023)\end{array}$ & $\begin{array}{l}0.036 * * \\
(0.019)\end{array}$ & $\begin{array}{c}0.025 \\
(0.021)\end{array}$ & $\begin{array}{c}0.051 * * * \\
(0.021)\end{array}$ \\
\hline $\begin{array}{l}\text { Log(disp. income) age } \\
47\end{array}$ & $\begin{array}{c}0.056^{* * *} \\
(0.017)\end{array}$ & $\begin{array}{c}0.103^{* * *} \\
(0.003)\end{array}$ & $\begin{array}{c}0.013 \\
(0.019)\end{array}$ & $\begin{array}{c}0.029 \\
(0.025)\end{array}$ & $\begin{array}{c}0.056 * * * \\
(0.017)\end{array}$ \\
\hline $\begin{array}{l}\text { Log(long-run disp. } \\
\text { income) }\end{array}$ & $\begin{array}{c}0.045 * * * \\
(0.013)\end{array}$ & $\begin{array}{c}0.065^{* * *} \\
(0.021)\end{array}$ & $\begin{array}{l}0.025^{*} \\
(0.019)\end{array}$ & $\begin{array}{c}0.03 * \\
(0.018)\end{array}$ & $\begin{array}{c}0.066 * * * \\
(0.024)\end{array}$ \\
\hline Annual days unemployed & $\begin{array}{l}-1.654^{*} \\
(0.944)\end{array}$ & $\begin{array}{l}-2.647^{*} \\
(1.504)\end{array}$ & $\begin{array}{l}-0.753 \\
(1.186)\end{array}$ & $\begin{array}{l}-0.232 \\
(1.328)\end{array}$ & $\begin{array}{c}-2.898 * * * \\
(1.355)\end{array}$ \\
\hline Share of years on welfare & $\begin{array}{c}-0.013 * * * \\
(0.005)\end{array}$ & $\begin{array}{c}-0.015^{* *} \\
(0.008)\end{array}$ & $\begin{array}{l}-0.011^{*} \\
(0.006)\end{array}$ & $\begin{array}{l}-0.007 \\
(0.007)\end{array}$ & $\begin{array}{c}-0.014 * * * \\
(0.006)\end{array}$ \\
\hline $\begin{array}{l}\text { Obese at enlistment } \\
\text { (males only) }\end{array}$ & $\begin{array}{l}-0.015^{* *} \\
(0.006)\end{array}$ & N/A & N/A & $\begin{array}{l}-0.003 \\
(0.008)\end{array}$ & $\begin{array}{c}-0.026 * * * \\
(0.01)\end{array}$ \\
\hline Early death & $\begin{array}{l}-0.009 * \\
(0.005)\end{array}$ & $\begin{array}{c}-0.014 * * \\
(0.009)\end{array}$ & $\begin{array}{l}-0.005 \\
(0.006)\end{array}$ & $\begin{array}{c}-0.01 \\
(0.008)\end{array}$ & $\begin{array}{l}-0.006 \\
(0.007)\end{array}$ \\
\hline Teenage mother & $\begin{array}{l}-0.011 \\
(0.008)\end{array}$ & N/A & N/A & $\begin{array}{c}-0.01 \\
(0.011)\end{array}$ & $\begin{array}{l}-0.009 \\
(0.010)\end{array}$ \\
\hline
\end{tabular}

Notes: Each cell presents the coefficient of the time preferences dummy variable ( 0 if the child at age 13 probably or certainly prefers SEK 900 (USD 130) today versus SEK 9,000 (USD 130) in five years, or is indifferent, and 1 if it either probably or certainly prefers SEK 9,000 in five years) from a separate regression where the dependent variable is given in the left column. The sample consists of children born in Stockholm county in 1953. All regressions are estimated by OLS and control for dummies for month of birth, gender, educational level (3 levels) of the parent with the highest education, each parent's income (linearly) and each parent's year of birth (linearly). Long-term income is calculated as average over age 37-48. Low ability is defined as individuals who scored below average on the spatial ability test at age 13. $* * *=$ significant at the $1 \%$ level $* *=$ significant at the $5 \%$ level $^{*}=$ significant at the $10 \%$ level. 


\subsection{Early human capital as a mediator}

So far we have shown that time preferences are associated with both human capital investments and long-run labor market and health. As early human capital investments are strongly linked to labor market performance, it is interesting to ask to what extent the relationship between time preferences and long-run outcomes operates through human capital. To investigate this we ran regressions where we controlled for educational attainment as well as our measure of spatial ability at age 13. Our results, presented in Table 6 and Table 7, reveal that controlling for spatial ability does not affect our estimates of the long-run relationship in any meaningful way. However, when including controls for educational attainment the point estimates fall substantially. Most of the estimates are no longer statistically significant and many are also close to zero. This is true both when it comes to earnings and income and also for our other measures of labor supply and health.

From this evidence, we conclude that (1) the relationship between time preferences and outcomes does not seem to be driven by intelligence and (2) that the association between time preferences and lifetime outcomes seems to be explained by the positive relationship between time preferences and educational attainment. The latter result is potentially important in the sense that if time preferences are malleable and to some degree truly affect the outcomes, our results imply that early interventions that make individuals more future-oriented potentially can bring life lasting benefits. 
Table 6. Time preferences and income over life: with and without controlling for ability and educational attainment

\begin{tabular}{|c|c|c|c|c|c|c|c|c|}
\hline & \multicolumn{2}{|c|}{$\log$ (Earnings) } & \multirow[b]{2}{*}{ Age 47} & \multirow[b]{2}{*}{$\begin{array}{l}\text { Long-term } \\
\text { income }\end{array}$} & \multicolumn{2}{|c|}{$\log ($ Disposable income) } & \multirow[b]{2}{*}{ Age 47} & \multirow[b]{2}{*}{$\begin{array}{l}\text { Long-term } \\
\text { income }\end{array}$} \\
\hline & Age 27 & Age 37 & & & Age 27 & Age 37 & & \\
\hline \multicolumn{9}{|c|}{ A. Baseline (as in Table 2) } \\
\hline $\begin{array}{l}\text { Timing of reward: } \\
\text { Immediate or indifferent }\end{array}$ & Ref. & Ref. & Ref. & Ref. & Ref. & Ref. & Ref. & Ref. \\
\hline Delay & $\begin{array}{l}0.049 * * \\
(0.023)\end{array}$ & $\begin{array}{l}0.044^{* *} \\
(0.020)\end{array}$ & $\begin{array}{l}0.060 * * * \\
(0.023)\end{array}$ & $\begin{array}{l}0.071 * * * \\
(0.024)\end{array}$ & $\begin{array}{l}0.046 * * \\
(0.021)\end{array}$ & $\begin{array}{l}0.042^{* * *} \\
(0.015)\end{array}$ & $\begin{array}{l}0.056^{* * *} \\
(0.017)\end{array}$ & $\begin{array}{l}0.045 * * * \\
(0.013)\end{array}$ \\
\hline Full set of controls & Incl. & Incl. & Incl. & Incl. & Incl. & Incl. & Incl. & Incl. \\
\hline R-squared & 0.055 & 0.093 & 0.053 & 0.052 & 0.054 & 0.045 & 0.048 & 0.062 \\
\hline Observations & 11,537 & 11,032 & 10,392 & 11,456 & 11,648 & 11,556 & 11,252 & 11,193 \\
\hline \multicolumn{9}{|c|}{ B. Controlling for ability at age 13} \\
\hline Immediate or indifferent & Ref. & Ref. & Ref. & Ref. & Ref. & Ref. & Ref. & Ref. \\
\hline Delay & $\begin{array}{l}0.046 * * \\
(0.023)\end{array}$ & $\begin{array}{l}0.036^{*} \\
(0.020)\end{array}$ & $\begin{array}{l}0.044^{*} \\
(0.023)\end{array}$ & $\begin{array}{l}0.051 * * \\
(0.024)\end{array}$ & $\begin{array}{l}0.042 * * \\
(0.021)\end{array}$ & $\begin{array}{l}0.034 * * \\
(0.015)\end{array}$ & $\begin{array}{l}0.042 * * \\
(0.017)\end{array}$ & $\begin{array}{l}0.034 * * * \\
(0.012)\end{array}$ \\
\hline Ability & Incl. & Incl. & Incl. & Incl. & Incl. & Incl. & Incl. & Incl. \\
\hline Full set of controls & Incl. & Incl. & Incl. & Incl. & Incl. & Incl. & Incl. & Incl. \\
\hline R-squared & 0.056 & 0.097 & 0.062 & 0.065 & 0.054 & 0.051 & 0.058 & 0.074 \\
\hline Observations & 11,535 & 11,030 & 10,390 & 11,454 & 11,646 & 11,554 & 11,250 & 11,191 \\
\hline \multicolumn{9}{|c|}{ C. Controlling for educational attainment } \\
\hline Immediate or indifferent & Ref. & Ref. & Ref. & Ref. & Ref. & Ref. & Ref. & Ref. \\
\hline Delay & $0.039 *$ & 0.013 & 0.013 & 0.012 & $0.038 *$ & 0.019 & 0.015 & 0.012 \\
\hline & $(0.023)$ & $(0.020)$ & $(0.022)$ & $(0.024)$ & $(0.022)$ & $(0.014)$ & $(0.016)$ & $(0.012)$ \\
\hline Educ. attainment & Incl. & Incl. & Incl. & Incl. & Incl. & Incl. & Incl. & Incl. \\
\hline Ability & Incl. & Incl. & Incl. & Incl. & Incl. & Incl. & Incl. & Incl. \\
\hline Full set of controls & Incl. & Incl. & Incl. & Incl. & Incl. & Incl. & Incl. & Incl. \\
\hline R-squared & 0.063 & 0.131 & 0.122 & 0.134 & 0.062 & 0.080 & 0.124 & 0.147 \\
\hline Observations & 11,330 & 11,030 & 10,362 & 11,413 & 11,431 & 11,554 & 11,214 & 11,191 \\
\hline
\end{tabular}


Table 7. The link between time preferences and welfare, unemployment, obesity, death and teenage pregnancy with and without controlling for ability and educational attainment

\begin{tabular}{|c|c|c|c|c|c|}
\hline & $\begin{array}{l}\text { Share of } \\
\text { years on } \\
\text { welfare }\end{array}$ & $\begin{array}{l}\text { Annual } \\
\text { unemploy } \\
\text { ment days }\end{array}$ & $\begin{array}{l}\text { Obese at } \\
\text { enlistment }\end{array}$ & Early death & $\begin{array}{l}\text { Teenage } \\
\text { mother }\end{array}$ \\
\hline \multicolumn{6}{|c|}{ A. Baseline (as in Table 3) } \\
\hline \multicolumn{4}{|c|}{ Timing of reward: } & Ref. & Ref. \\
\hline Delay & $\begin{array}{l}-0.013^{* * *} \\
(0.005)\end{array}$ & $\begin{array}{l}-1.654 * \\
(0.944)\end{array}$ & $\begin{array}{l}-0.015 * * \\
(0.006)\end{array}$ & $\begin{array}{l}-0.009 * \\
(0.005)\end{array}$ & $\begin{array}{l}-0.011 \\
(0.008)\end{array}$ \\
\hline Full set of controls & Incl. & Incl. & Incl. & Incl. & Incl. \\
\hline R-squared & 0.021 & 0.006 & 0.796 & 0.005 & 0.012 \\
\hline Observations & 11,696 & 11,657 & 11,907 & 11,907 & 5,860 \\
\hline \multicolumn{6}{|c|}{ B. Controlling for ability at age 13} \\
\hline Immediate/indifferent & Ref. & Ref. & Ref. & Ref. & Ref. \\
\hline Delay & $\begin{array}{l}-0.009 * \\
(0.005)\end{array}$ & $\begin{array}{l}-1.312 \\
(0.951)\end{array}$ & $\begin{array}{l}-0.014 * * \\
(0.006)\end{array}$ & $\begin{array}{l}-0.008 \\
(0.005)\end{array}$ & $\begin{array}{l}-0.010 \\
(0.008)\end{array}$ \\
\hline Ability & Incl. & Incl. & Incl. & Incl. & Incl. \\
\hline Full set of controls & Incl. & Incl. & Incl. & Incl. & Incl. \\
\hline R-squared & 0.036 & 0.009 & 0.796 & 0.007 & 0.015 \\
\hline Observations & 11,694 & 11,655 & 11,905 & 11,905 & 5,860 \\
\hline \multicolumn{6}{|c|}{ C. Controlling for educational attainment } \\
\hline Immediate/indifferent & Ref. & Ref. & Ref. & Ref. & Ref. \\
\hline Delay & $\begin{array}{l}-0.004 \\
(0.005)\end{array}$ & $\begin{array}{l}-0.504 \\
(0.945)\end{array}$ & $\begin{array}{l}-0.012 * \\
(0.007)\end{array}$ & $\begin{array}{l}-0.001 \\
(0.004)\end{array}$ & $\begin{array}{l}-0.007 \\
(0.008)\end{array}$ \\
\hline Educ. attainment & Incl. & Incl. & Incl. & Incl. & Incl. \\
\hline Ability & Incl. & Incl. & Incl. & Incl. & Incl. \\
\hline Full set of controls & Incl. & Incl. & Incl. & Incl. & Incl. \\
\hline R-squared & 0.077 & 0.029 & 0.801 & 0.010 & 0.025 \\
\hline Observations & 11,643 & 11,605 & 11,643 & 11,643 & 5,729 \\
\hline \multicolumn{6}{|c|}{$\begin{array}{l}\text { Notes: The table shows the coefficient of the time preferences dummy variable (0 if the child at age } 13 \\
\text { probably or certainly prefers SEK } 900 \text { (USD 130) today versus SEK 9,000 (USD 130) in five years, or is } \\
\text { indifferent, and } 1 \text { if it either probably or certainly prefers SEK 9,000 in five years). Each column } \\
\text { represents a separate regression. All regressions are estimated by OLS The sample consists of children } \\
\text { born in Stockholm county in } 1953 \text {. All regressions control with dummies for month of birth, gender } \\
\text { educational level ( } 3 \text { levels) of the parent with the highest education, each parent's income (linearly) and } \\
\text { each parent's year of birth (linearly). The dependent variables Share of years on welfare and Annual } \\
\text { unemployment days are calculated as the average over age } 37-48 \text {. *** significant at the } 1 \% \text { level } * *= \\
\text { significant at the } 5 \% \text { level* = significant at the } 10 \% \text { level. }\end{array}$} \\
\hline
\end{tabular}


In an influential study, Becker and Mulligan (1997) posit that people could learn to be more future-oriented. However, the evidence on the malleability of time preferences is mixed. PerezArce (2011) demonstrates empirically that college students in Mexico who were randomly admitted from a pool of applicants were more patient than individuals in the control group, which indicates that education has an impact on time preferences. Other studies show that exogenous events govern individual time preferences. Voors et al. (2012) use a field experiment in Burundi to examine the consequences of exposure to conflict on time preferences. The results suggest that individuals who are plausibly exogenously exposed to violence have higher discount rates. Cullen (2011) shows estimates that Sri Lankan workers who were exposed to the 2005 tsunami exhibited more patience than those who happened to work just above the water mark and therefore were unaffected. Further, Bishai (2004) shows that time preferences rates tend to change substantially after age 29. Krupka and Stephens Jr. (2012) report that elicited discount rates appear to reflect market interest rates rather than individuals' time preferences, and discount rates are therefore malleable. Meier and Sprenger (2010a) find no indications for changes in the aggregate distributions of discount factors following approximately 1,400 individuals over a period of 2 years. The authors show that the observed one-year correlations in discount factors are low compared to the temporal correlation of "Big Five", but not compared to typical results based on single measures. Borghans et al. (2008) review the evidence of a number of cross-sectional studies which report that time preferences differ across age. Recent research has also suggested that active decision making and optimal default choices can potentially moderate high discount rates (e.g. Carroll et al. 2009). Time preferences therefore appear to be more malleable than for instance intelligence. This result has also been documented for personality traits. A large body of psychological research has stressed that personality traits may be influenced by the environment during childhood and that they do not stabilize until late during adolescence (e.g. Borghans et al. 2008).

\section{Conclusions}

This paper analyzes the relationship between time preferences and outcomes later in life. Early theoretical contributions posit that people with high discount rates invest less in their future than people who are more future-oriented. This motivates the question whether time preferences indeed play an important role in predicting important economic outcomes later in life. Using unique longitudinal data spanning over four decades, we find evidence that impatience is related especially to less educational attainment and to weaker performance in both compulsory and secondary school. The main contribution of the paper is that our analysis provides new evidence to a remarkably small literature on the role of time preferences when young for later in life 
outcomes. We show that high discount rates are related to lower incomes at middle age, more days in unemployment, higher risk of obesity and teen-age motherhood. The results are robust when controlling for important confounding factors such as parental income and education and cognitive ability of the child. Concerning the results on income, time preferences are strongly associated with income throughout all periods in life and the coefficients are sizable and almost always statistically significant. Both regarding early human capital investments and long-run income, patient males have better outcomes than patient females. The same holds for individuals who scored above average on a spatial ability test taken at age 13 . We also find that the relationship between time preferences and lifetime outcomes appears to be mediated by early human capital investments.

To the extent that our estimates capture causal effects, our analysis, in combination with earlier evidence that time preferences are malleable, motivates a policy discussion about reducing time preferences rates. It indicates that the returns of such interventions are potentially high. More research is needed to corroborate our findings, especially data with other measures of time preferences would be an important complement to our analysis.

\section{References}

Becker, G. (1964), "Human Capital, a Theoretical and Empirical Analysis with Special Reference to Education,” Columbia University Press, NY.

Becker, G. and Mulligan, C. (1997), “The Endogenous Determination of Time Preferences,” Quarterly Journal of Economics 112 (3), 729-758.

Bettinger, E. and Slonim, R. (2007), “Patience among Children,” Journal of Public Economics 91 (1-2), 343-363.

Bickel, W., Odum, A., Madden, G. (1999), "Impulsivity and cigarette smoking: delay discounting in current, never, and exsmokers,” Psychopharmacology 146 (4), 447-454.

Bishai, D. (2004), "Does Time Preferences Change with Age?,” Journal of Population Economics 17 (4), 583-602.

Borghans, L., Duckworth, A., Heckman, J., and terWeel, B. (2008), "The Economics and Psychology of Personality Traits,” Journal of Human Resources 43 (4), 972-1059.

Borghans, L. and Golsteyn, B. (2006), “Time Discounting and the Body Mass Index, Evidence from the Netherlands,” Economics and Human Biology 4 (1), 39-61.

Borghans, L., Golsteyn, B., Heckman, J. and Humphries, J.E. (2012), “IQ, Achievement and Personality,” Unpublished Manuscript, University of Chicago. 
Bound, J., Jaeger, D. and Baker, R. (1995), "Problems with Instrumental Variables Estimation when the Correlation Between the Instruments and the Endogenous Explanatory Variables is Weak,”Journal of the American Statistical Association 90, 443-450.

Burks, S. V., Carpenter, J.P. Goette, L. and Rustichini, A. (2009), "Cognitive Skills Affect Economic Preferences, Strategic Behavior, and Job Attachment," Proceedings of the National Academy of Sciences 106 (19), 7745-7750.

Böhlmark, A. and Lindquist, M. J. (2006), "Life-Cycle Variation in the Association between Current and Lifetime Income: Replication and Extension for Sweden,” Journal of Labor Economics 24 (4), 879-96.

Cadena, B. and Keys, B. (2011), "Human Capital and the Lifetime Costs of Impatience," Unpublished manuscript, Harris School of Public Policy, University of Chicago.

Carroll, G., Choi, J., Laibson, D., Madrian, B.andMetrick, A. (2009), “Optimal Defaults and Active Decisions,” Quarterly Journal of Economics 124 (4), 1639-1674.

Castillo, M., Ferraro, P., Jordan J. and Petrie, R. (2011), “The Today and Tomorrow of Kids: Time Preferences and Educational Outcomes of Children,” Journal of Public Economics 95 (11- 12), 1377-85.

Chabris, C. F., Laibson, D., Morris, C. L., Schuldt, J. P. and Taubinsky, D. (2008), "Individual Laboratory-Measured Discount Rates Predict Field Behavior,” Journal of Risk and Uncertainty 37, 237-269.

Cullen, M. (2011), “Catastrophes and Time Preference: Evidence from the Indian Ocean Earthquake,” Unpublished Manuscript, University of California at San Diego.

DellaVigna, S. and Paserman, D. (2005), “Job Search and Impatience,” Journal of Labor Economics 23 (3), 527-588.

Dohmen, T., Falk, A., Huffman, D. and Sunde, U. (2010), “Are Risk Aversion and Impatience Related to Cognitive Ability?,” American Economic Review 100 (3), 1238-1260.

Frederick, S., Loewenstein, G. and O’Donoghue, T. (2002), “Time Discounting and Time Preferences: A Critical Review,” Journal of Economic Literature XL, 351-401.

Fuchs, V. (1982), “Time Preferences and Health: an Exploratory Study,” in V. Fuchs, ed., Economic Aspects of Health, Chicago, University of Chicago Press. 
Gaudecker, H-M von, Soest, A. van, and Wengström, E. (2011), "Experts in Experiments: How Selection Matters for Estimated Distributions of Risk Preferences,” IZA Discussion Paper 5575.

Grossman, M. (1972), “On the Concept of Health Capital and the Demand for Health,” Journal of Political Economy80 (2), 223-255.

Haider, S. and Solon, G. (2006), "Life-Cycle Variation in the Association between Current and Lifetime Earnings,” American Economic Review 96 (4), 1308-1320.

Heckman, J., Stixrud, J. and Urzua, S. (2006), “The Effects of Cognitive and Noncognitive Abilities on Labor Market Outcomes and Social Behavior,” Journal of Labor Economics 24 (3), 411-482.

Heineck, G. and Anger, S. (2010), “The Returns to Cognitive Abilities and Personality Traits in Germany,” Labour Economics 17 (3), 535-546.

Jamison, J., Karlan, D. and J. Zinman (2012), “Measuring Risk and Time Preferences and Their Connections with Behavior,” forthcoming in Handbook of Experimental Economics

Krupka, E.L. and Stephens, M. (2012), “The Stability of Measured Time Preferences,” forthcoming in Journal of Economic Behavior and Organization.

Laibson, D. (1994), “Self-Control and Saving,” MIT mimeo.

Laibson, D. (1997), “Golden Eggs and Hyperbolic Discounting,” Quarterly Journal of Economics, 112 (2), 443-77.

Lindahl, L. (2011), “A comparison of family and neighborhood effects on grades, test scores, educational attainment and income - evidence from Sweden,” Journal of Economic Inequality 9 (2), 207-226.

Meier, S. and Sprenger, C. (2010a) “Stability of Time Preferences,” IZA DP No. 4756.

Meier, S. and Sprenger, C. (2010b) "Present-Biased Preferences and Credit Card Borrowing," American Economic Journal: Applied Economics 2, 193-210.

Mincer, J. (1958), “Investment in Human Capital and Personal Income Distribution,” Journal of Political Economy 66 (4), 281-302.

Mischel, W., Shoda, Y, and Peake, E K. (1988) "The Nature of Adolescent Competencies Predicted by Preschool Delay of Gratification,” Journal of Personality and Social Psychology 54, $687-696$. 
Mischel, W., Shoda, Y. and Rodriguez, M. (1989), "Delay of Gratification in Children,” Science 244 (4907), 281-302.

Moffitt, T.E., Arseneault, L., Belsky, D., Dickson, N., Hancox, R.J., Harrington, H., Houts, R., Poulton, R., Roberts, B.W., Ross, S., Sears, N.R., Thomsom, W.M. and Caspi, A. (2011), “A Gradient of Childhood Self-Control Predicts Health, Wealth, and Public Safety,” Proceedings of the National Academy of Sciences 108 (7), 2693-2698.

Perez-Arce, F. (2011), “The Effect of Education on Time Preferences,” Rand Labor and Population Series WR-844.

Samuelson, P. (1937), “A Note on Measurement of Utility,” Review of Economic Studies 4 (2), 155-167.

Segal, C. (2012), "Working When No One is Watching: Motivation, Test Scores and Economic Success,” Management Science, forthcoming.

Shamosh, N. and Gray, J. (2007), "Delay Discounting and Intelligence: A Meta-Analysis," Unpublished manuscript, Department of Psychology, Yale University.

Shoda, Y., Mischel, W. and Peake, P. (1990), "Predicting Adolescent Cognitive and SelfRegulatory Competencies from Pre-School Delay of Gratification: Identifying Diagnostic Conditions,” Developmental Psychology 26 (6), 978-986.

Stenberg, S.-Å.andVågerö, D. (2006), “Cohort Profile: The Stockholm Birth Cohort of 1953,” International Journal of Epidemiology 35, 546-548.

Sutter, M., Kocher, M., Rutzler, D. and Trautmann, S. (2011), "Impatience and Uncertainly: Experimental Decisions Predict Adolecents‘ Field Behavior,” forthcoming in American Economic Review.

Voors, M.J., Nillesen, E.E.M., Bulte, E.H., Lensink, B.W., Verwimp, P. and Soest, D.P. van (2012), "Violent Conflict and Behavior: a Field Experiment in Burundi," forthcoming in American Economic Review. 


\section{Appendix}

Table A 1. Descriptive statistics

Mean

Standard deviation

Outcome measures:

Compulsory school GPA (scale 1-5)

$3.180 \quad 0.770$

Upper secondary school GPA (scale 1-5)

3.340

0.650

Completed upper secondary school

0.503

0.500

Completed college

$0.189 \quad 0.391$

Enrolled in science track in upper sec. school

0.215

0.411

Military enlistment test score (scale 1-9)

5.180

2.490

log(earnings) at age 27

$6.186 \quad 0.802$

log(earnings) at age 37

12.121

0.707

log(earnings) at age 47

12.360

0.820

$\log$ (long-term earnings)

12.094

0.901

$\log$ (disposable income) at age 27

10.785

0.785

$\log$ (disposable income) at age 37

11.646

0.526

$\log$ (disposable income) at age 47

12.075

0.667

log(long-term disposable income)

11.942

0.501

Average annual days unemployed

13.336

32.582

Share of years on welfare

0.060

0.162

Obese at enlistment (males only)

0.055

0.050

Early death (deceased by age 50)

0.027

0.163

Teenage mother (first birth <age 20)

0.026

0.158

Control variables:

Female

0.492

0.500

Income father (SEK)

23133

20439

Income mother (SEK)

4289

6457

Age father at birth

31.168

6.491

Age mother at birth

IQ at age 13

22.742

7.124

Achievement test scores at age 13

68.437

17.965

Education of parent with highest level of education

Compulsory school

0.746

0.435

Upper secondary school

0.167

0.373

College

0.087

0.282

Notes: The table shows summary statistics for variables included in the analysis. The sample consists of all children born in Stockholm county in $1953(\mathrm{~N}=11,907)$. 
Table A 2. The relationship between time preferences and individual characteristics

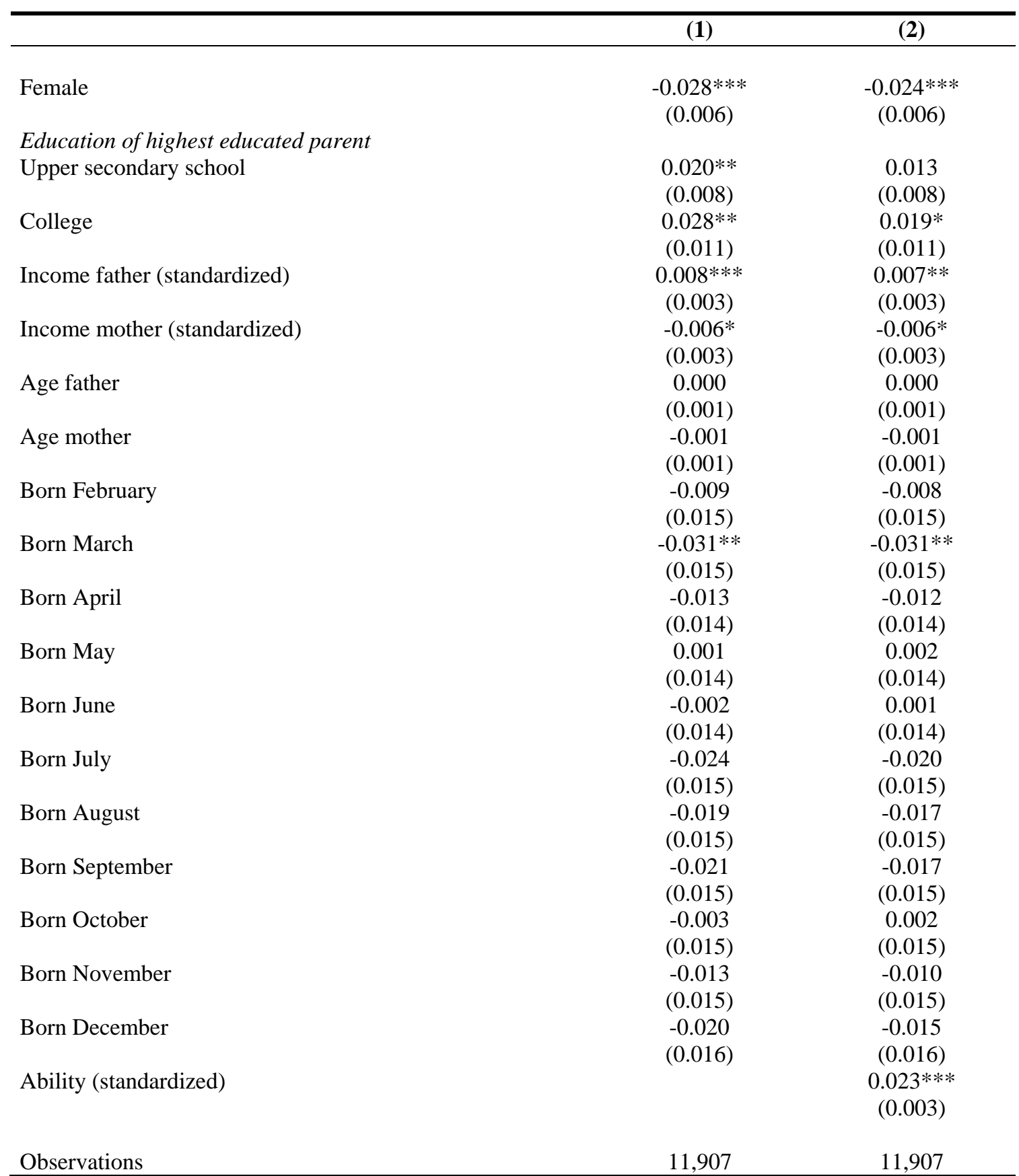

Notes: The table shows the OLS coefficients on variables used as controls in the empirical analysis. Dependent variable $=1$ if the respondent certainly or probably prefers to delay reward and zero otherwise The sample consists of children born in Stockholm county in 1953. *** = significant at the $1 \%$ level **= significant at the $5 \%$ level* = significant at the $10 \%$ level. 
Figure 1. Distribution of time preferences

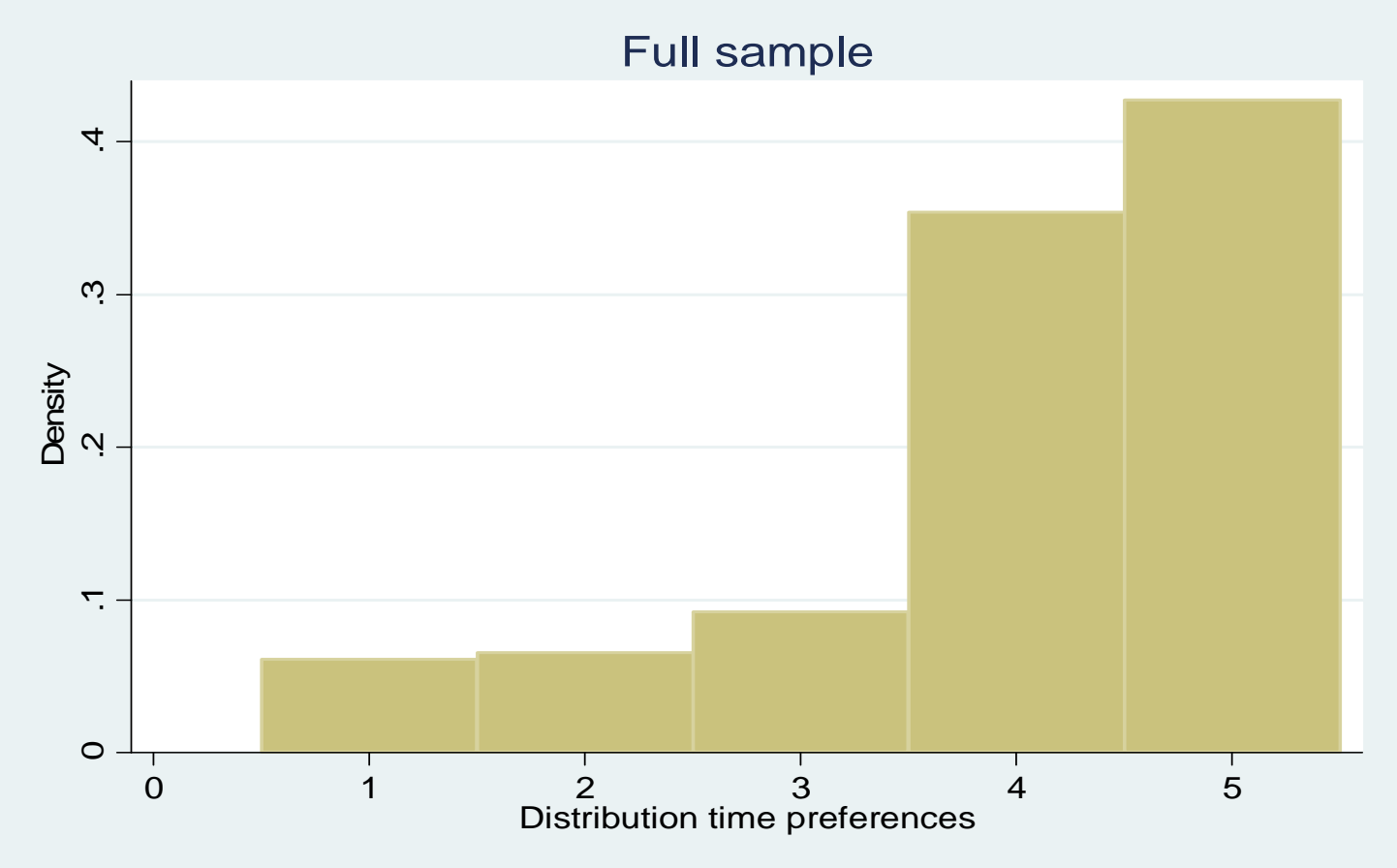

Notes: Figure 1 shows the distribution of answers to the question: "If you had to choose between SEK 900 [USD 130] now versus SEK 9,000 [USD 1,300] in five years, which would you choose?”. Categories (1) to (5) represents respondents stating: "Certainly SEK 900 now" (1), "Probably SEK 900 now" (2), "Cannot choose" (3), "Probably SEK 9,000 in five years" (4), "Certainly SEK 9,000 in five years" (5). The sample consists of all children born in Stockholm county in the year 1953. The survey was administrated in to children aged 13 . The number of respondents is 11,907 .

\section{Questions used in factor analysis}

The questions which are answered in the same survey that contains our preferred measure of time preferences read:

1. If school were completely voluntary and you could quit tomorrow or stay if you wanted to, what would you do if you could decide yourself?

2. Do you think about how things are going to be for you when you are grown up?

3. Do you think it is important what you are when you grow up or does it not matter?

4. Do you compare your future prospects with other's?

5. Do you like thinking about what you will do when you are grown up?

We elicited the principal component of these questions. Cronbach's alpha, a measure of internal consistency is 0.53 which indicates that the internal consistency of the measure is acceptable but not very high and that the results of the robustness analysis should be read with some caution.

Although the Eigenvalue of the factor analysis indicates that only one factor could be elicited, it appears that question 1 and 3 pick up a different factor than 2, 4 and 5. Question 1 correlates highly with question $3(0.240)$ but not much with the other questions. Question 2, 4 
and 5 show high correlations (2 and 4: 0.276; 2 and 5: 0.449; 4 and 5: 0.239). It seems therefore that question 1 and 3 are picking up a different latent factor than question 2, 4 and 5. Question 1 and 3 also correlate significantly and in the expected direction with our time preference dummy variable, while questions 2, 4 and 5 do not. The correlations between 1 and 3 and our time preference dummy variable are respectively $0.119(\mathrm{p}=0.000)$ and $0.056(\mathrm{p}=0.000)$. The correlation with question 4 is unexpectedly negative $-0.027(\mathrm{p}=0.003)$ and the correlations with questions $2(\mathrm{p}=0.667)$ and $5(\mathrm{p}=0.914)$ are insignificant.

In the robustness analysis in the main text, we use the principal component of all five questions. If we instead run regressions of all outcomes on each question separately, questions 1 and 3 have remarkably similar signs and significance levels as compared to our (dummy) time preference variable. Out of the 19 outcomes we consider in our analyses, question 1 always has the same sign and (always a higher) significance level as our dummy variable. Question 3 has 15 times the same sign and significance level. 